\title{
A Three-year retrospective analysis of tumour like conditions of the Ovary in Tirunelveli Medical College Hospital
}

\author{
Author \\ Dr M. Malathi, MD \\ Assistant Professor of Pathology, Chengalpattu Medical College, Chengalpattu \\ Email: malathimashok@gmail.com, Mob: +91-9886724707
}

\section{Introduction}

Ovaries are very complex organs in terms of embryology and histology. It undergoes cyclical changes from adolescence to menopause and gives rise to different types of cells, which has capacity to produce different type of lesions and tumours ${ }^{1}$.

A number of non-neoplastic lesions can occur from neonatal period to postmenopausal age group. Most are functional in nature and resolve with minimal treatment. Some of the non-neoplastic lesions like massive edema of ovary, stromal hyperplasia, large follicular cyst, pregnancy luteomas and granulomatous inflammation can be confused with neoplasm clinically, intraoperatively and on morphological examination. The main aim lies in distinguishing ovarian neoplasmsfrom the wide spectrum of non-neoplastic lesions. Despite the new techniques like imaging studies, the diagnosis is mainly dependent upon histopathological examination.

The present study is being undertaken to review in detail the different varieties of ovarian lesions in and around Tirunelveli and assess their characteristics with regards to incidence, age and histopathological appearances.

\section{Aim and Objectives}

1. To determine the nature of non-neoplastic lesions presented to the department of Pathology, Tirunelveli Medical College.

2. To ascertain the frequency and distribution of ovarian lesions among various age group and to correlate them with the clinical features.

3. To study the histomorphological diversity of various non neoplastic lesions of ovary.

\section{Materials and Methods}

Our study is a retrospective study carried out in the Department of Pathology, Tirunelveli Medical College, Tirunelveli from January 2008 to December 2010. This study was undertaken to find out the incidence and analyse the histomorphological patterns of ovarian lesions in and around Tirunelveli.

Clinical details of the patient including the age, parity, hormonal status and examination findings were recorded. The laboratory and radiological parameters were recorded.

Gross and microscopic features of all the cases were noted from the records available in the Department of Pathology. Further sections were taken from the block retrieved from the store and stained with 
hematoxylin and Eosin. Finally histopathological findings of all the cases were analysed.

\section{Inclusion criteria}

Patients of all ages who are preoperatively diagnosed as having ovarian lesions.

\section{Exclusion criteria}

Neoplastic lesions and incidently found ovarian lesions in patients operated for other gynaecological problems were excluded from the study.

\section{Observations and Results}

Table 1 Distribution of neoplastic and nonneoplastic lesions

\begin{tabular}{|c|c|c|c|c|}
\hline \multicolumn{2}{|c|}{$\begin{array}{c}\text { Non neoplastic } \\
\text { lesions }\end{array}$} & \multicolumn{2}{|c|}{ Neoplastic lesions } & Total \\
\hline $\begin{array}{c}\text { No of } \\
\text { cases }\end{array}$ & $(\%)$ & $\begin{array}{c}\text { No } \\
\text { of } \\
\text { cases }\end{array}$ & $(\%)$ & \\
\hline 38 & 18.71 & 165 & 81.28 & $203(100 \%)$ \\
\hline
\end{tabular}

As shown in Table 1, among 203 ovarian lesions, 165 cases were neoplastic lesions, accounting for $81.28 \%, 38$ cases were non neoplastic accounting for $18.71 \%$. Increased incidence of neoplastic lesions was observed in our study.

Table 2 Mode of presentation

\begin{tabular}{|l|c|c|c|}
\hline S.No & Clinical presentation & No of cases & \% \\
\hline 1 & Abdominal pain & 26 & 68.42 \\
\hline 2 & $\begin{array}{c}\text { Abnormal uterine } \\
\text { bleeding }\end{array}$ & 12 & 31.58 \\
\hline & Total & 38 & \\
\hline
\end{tabular}

As shown in Table 2, among 38 cases, 26 cases were presented with abdominal pain.

Table 3 Age of the patient and non-neoplastic lesions

\begin{tabular}{|l|c|c|c|}
\hline \multirow{2}{*}{ S.No } & \multirow{2}{*}{ Type of cysts } & \multicolumn{2}{|c|}{ Age of the patient } \\
\cline { 3 - 4 } & & Range & Mean \\
\cline { 3 - 4 } & & Years & Years \\
\hline 1 & Endometriotic cyst & $23-70$ & 33.6 \\
\hline 2 & Follicular cyst & $30-48$ & 41.25 \\
\hline 3 & Corpus luteal cyst & $27-38$ & 33.25 \\
\hline 4 & $\begin{array}{c}\text { Massive edema of } \\
\text { ovary }\end{array}$ & 48 & 48 \\
\hline 5 & Tuboovarian abscess & $30-38$ & 34 \\
\hline 6 & Inclusion cyst & $22-77$ & 47 \\
\hline
\end{tabular}

Table 4 Size of the lesions

\begin{tabular}{|l|c|c|c|}
\hline \multirow{2}{*}{ S.No } & Type of cysts & \multicolumn{2}{|c|}{ Size of the lesion } \\
\cline { 3 - 4 } & & Range & Mean \\
\cline { 3 - 4 } & & Cms & Cms \\
\hline 1 & Endometriotic cyst & $4-12$ & 8 \\
\hline 2 & Follicular cyst & $4-7$ & 5.5 \\
\hline 3 & Corpus luteal cyst & $4-12$ & 8 \\
\hline 4 & $\begin{array}{c}\text { Massive edema of } \\
\text { ovary }\end{array}$ & 5 & 8 \\
\hline 5 & Tuboovarian abscess & $5-7$ & 6 \\
\hline 6 & Inclusion cyst & $6-7$ & 6.5 \\
\hline
\end{tabular}

As shown in Table $3 \& 4$, the mean age of the endometriotic cyst was 33.6 years, of follicular cyst was 41.22years, of luteal cyst was 33.25years, of inclusion cyst was 47 years, of tuboovarian abscess was 47 years. The mean diameter of endometriotic cyst was $8 \mathrm{cms}$, of follicular cyst $5.5 \mathrm{cms}$, of luteal cyst $8 \mathrm{cms}$, of inclusion cyst was $6.5 \mathrm{cms}$, of tuboovarian abscess was $6 \mathrm{cms}$ in diameter.

Table 5 Distribution of non-neoplastic lesions

\begin{tabular}{|l|c|c|c|}
\hline S.No & Types of lesions & No of cases & \% \\
\hline 1 & Follicular cyst & 8 & 21.05 \\
\hline 2 & Luteal cyst & 4 & 10.52 \\
\hline 3 & Inclusion cyst & 3 & 7.89 \\
\hline 4 & Endometriotic cyst & 20 & 52.63 \\
\hline 5 & Massive edema of ovary & 1 & 2.63 \\
\hline 6 & Tuboovarian abscess & 2 & 5.26 \\
\hline \multicolumn{2}{|c|}{ Total } & 38 & 100 \\
\hline
\end{tabular}

As shown in Table 5, the most common non neoplastic cyst diagnosed was endometriotic cyst (20 cases, $52.63 \%$ ), followed by follicular cysts ( 8 cases, $21.05 \%$ )

Table 6 Gross morphology

\begin{tabular}{|l|c|c|c|}
\hline S.No & Gross morphology & $\begin{array}{c}\text { No of cases } \\
(\mathbf{\%})\end{array}$ & $\begin{array}{c}\text { Total } \\
(\mathbf{\%})\end{array}$ \\
\hline 1 & Cystic & 20 & 52.64 \\
\hline 2 & Solid & 5 & 13.15 \\
\hline 3 & Solid and cystic & 13 & 34.21 \\
\hline & Total & 38 & 100 \\
\hline
\end{tabular}

As shown in Table 6, most of lesions are cystic in nature.

\section{Histomorphological patterns Endometriotic cyst}

This was the most common non neoplastic cyst found in this study [52.63\%]. Most commonly it was seen in $2^{\text {nd }}$ and $3^{\text {rd }}$ decade. Abdominal pain was the common presentation. All were unilateral cyst 
with a mean size of $8 \mathrm{cms}$ in diameter. Macroscopically, most of the cysts were uniloculated with haemorrhagic content. Microscopic examination showed a cyst wall lined by attenuated endometrial glands admixed with stroma showing haemosiderophages and haemorrhages.

\section{Follicular cyst}

This was the second most common lesion, contributes $21 \%$ of total non neoplastic lesions. The mean age of presentation was 41 years. Majority of the cases were unilateral. The mean size of the tumour was $5.5 \mathrm{cms}$ in diameter. Three patients were presented with abnormal uterine bleeding. Microscopically cysts were lined by inner granulosa and outer layer of theca cells.

\section{Corpus luteal cyst}

It accounts for $10.52 \%$ of non-neoplastic lesions. The mean age of presentation was 30years. The mean size of the cyst was $8 \mathrm{cms}$. Macroscopically the cyst wall convoluted and yellow in colour. Microscopically it was lined by luteinized granulosa cells interrupted by wedges of theca lutein cells. One case of massive ovarian edema was reported. Cut section showed homogenous, glistening appearance. Microscopically, edematous ovarian stroma was seen sparing the cortex.

\section{Discussion}

A study conducted by De Kroon et al [2004] $]^{2}$ in United states reported that two third of ovarian cysts were found to be non-neoplastic. in India [Meerut], Gupta et al $[2007]^{3}$ reported $58.79 \%$ of nonneoplastic lesions and $41.2 \%$ are neoplastic lesions among 282 cases, whereas another study done in Mumbai by Bhattacharya et al ${ }^{4}$ reported that out of 270 cases $7.41 \%$ were non-neoplastic, $92.51 \%$ were neoplastic. Our present study showed that, out of 203 cases, 38 [18.1\%] cases were non neoplastic, 165[81.28\%] cases were neoplastic lesions. Our study correlates with the study of Bhattacharya et al, not with other studies.
Table 7 Comparison of Incidence of non-neoplastic lesions with other studies

\begin{tabular}{|l|c|c|c|c|}
\hline S.No & \multirow{2}{*}{$\begin{array}{c}\text { Non neoplastic } \\
\text { lesions }\end{array}$} & $\begin{array}{c}\text { Samina } \\
\text { et al }\end{array}$ & $\begin{array}{c}\text { Pudasaini } \\
\text { et al }\end{array}$ & $\begin{array}{c}\text { Present } \\
\text { study }\end{array}$ \\
\hline 1 & Follicular cyst & $22.24 \%$ & $4.8 \%$ & $3.9 \%$ \\
\hline 2 & Corpus luteal cyst & $34.83 \%$ & $13.7 \%$ & $1.9 \%$ \\
\hline 3 & Endometriotic cyst & $10.78 \%$ & $5.9 \%$ & $9.8 \%$ \\
\hline
\end{tabular}

In the present study endometriotic cyst was the most common non neoplastic lesion, contributes $9.8 \%$ of total ovarian lesions [52.63\%]. This result contradicts other studies done by Samina Zaman et al[2010] and Gupta et al [2007] where almost half of the cases were contributed by Luteal cyst. [Table 7]

\section{Mean Age of Non-Neoplastic Lesions}

In the present study we found that they were commonly occurred between $3^{\text {rd }}$ and $4^{\text {th }}$ decade. This observation correlates with the studies conducted by Samina Zamina et al [2010] and Pudasaini et al [2011] (Table 8)

Table 8 Comparison of mean age of non-neoplastic lesions with other studies

\begin{tabular}{|l|c|c|c|c|}
\hline S.No & \multirow{2}{*}{$\begin{array}{c}\text { Non neoplastic } \\
\text { cysts }\end{array}$} & \multicolumn{3}{|c|}{ Authors } \\
\cline { 3 - 5 } & & \multicolumn{3}{|c|}{ Mean age(years) } \\
\cline { 3 - 5 } & & $\begin{array}{c}\text { Samina } \\
\text { Zaman } \\
\text { et al }\end{array}$ & $\begin{array}{c}\text { Pudasaini } \\
\text { et al }\end{array}$ & $\begin{array}{c}\text { Present } \\
\text { study }\end{array}$ \\
\hline 1 & Endometriotic cyst & 30.28 & 35.28 & 33.6 \\
\hline 2 & Follicular cyst & 37.67 & 39.1 & 41.25 \\
\hline 3 & Luteal cyst & 35.41 & 32.12 & 33.25 \\
\hline
\end{tabular}

Table 9 Comparison of mean age of non-neoplastic lesions with other studies

\begin{tabular}{|l|c|c|c|c|}
\hline \multirow{2}{*}{ S.No } & \multirow{2}{*}{$\begin{array}{c}\text { Non neoplastic } \\
\text { cysts }\end{array}$} & \multicolumn{3}{|c|}{ Authors } \\
\cline { 3 - 5 } & & \multicolumn{3}{|c|}{ Size (cms) } \\
\cline { 3 - 5 } & & $\begin{array}{c}\text { Samina } \\
\text { Zaman } \\
\text { et al }\end{array}$ & $\begin{array}{c}\text { Gupta } \\
\text { et al }\end{array}$ & $\begin{array}{c}\text { Present } \\
\text { study }\end{array}$ \\
\hline 1 & Endometriotic cyst & 5.98 & 5.5 & 8 \\
\hline 2 & Follicular cyst & 3.95 & 5.2 & 5 \\
\hline 3 & Luteal cyst & 3.76 & 6.1 & 8 \\
\hline
\end{tabular}

As shown in Table 9 in our study showed that the mean size of the cysts was slightly larger than the above mentioned studies. In the present study abdominal pain was the commonest symptom, which was comparable with the studies by Gupta et $\mathrm{al}^{3}$ and Wasim et $\mathrm{al}^{7}$. 


\section{Summary and Conclusion}

A histopathological study of ovarian non neoplastic lesions was undertaken in the Department of Pathology, Tirunelveli Medical College to know the occurrence of different type of lesions in this region. Out of 203 ovarian lesions, 38 cases were non neoplastic lesions. Endometriotic cyst was most common comprising of 20 cases [52.63\%], followed by follicular cysts [21.05\%].

Majority of the non-neoplastic lesions were unilateral cysts. Most commonly occurred in third decade and all the lesions were below $10 \mathrm{cms}$. Most commonly presented with abdominal pain.

Ovaries are prone for occurrence of neoplasms which gives the enormous burden and economic drain for the individual. In the younger age group it may hinder the active life. Hence it is essential to differentiate neoplasms from non-neoplastic lesion and to know the prevalence of it. Our study done in Tirunelveli Medical college correlated well with the studies undertaken in different parts of India.

Inspite of serological and radiological studies, histopathological examination remains the gold standard to rule out ovarian neoplasms.

\section{References}

1. Prabhakar BR, Maingi K. Ovarian tumoursprevalence in Punjab. Indian $\mathbf{J}$ pathol Microbiol 1989; 32: 276-81.

2. De Kroon $\mathrm{CD}$, Van der sandt HAGM, Jansen FW. Sonographic assessment of Nonmalignant ovarian cyst: Hum Reprod 2004; 19(9): 2138-43

3. Gupta SC, Singh PA, Mehrotra TN, Agarwal R. A Clinicopathological study of Ovarian tumours. Indian $\mathrm{J}$ pathol Microbiol 1986;29:354-62.

4. Bhattacharya MM, Shinde SD, Purandare VN. A Clinicopathological analysis of 270 ovarian tumours. J postgrad Med 1980; 26:103.

5. Zamana S, Majid S, Hussain M, Chugtai O, Mahboob J, Chugtai S. A retrospective study of ovarian tumours and tumour like conditions. J Ayub Med Coll. Abottabad. 2010; 104-8.

6. Pudasaini S, Lakey M, Thapa B, A study of ovarian cyst in a Tertiary hospital of Kathmandu valley, Nepal Med Coll J 2011; 13910:39-41

7. Wasim T, Majjroha, Siddiq S, Comparison of clinical presentation of Benign and Malignant ovarian tumours. J Pak Med Assoc 2009; 59(1): 18-21. 